\title{
Fungi Endofit dari Tanaman Secang (Caesalpinia sappan L) Sebagai Penghasil Senyawa Antioksidan
}

\author{
Endophytic Fungi from Secang (Caesalpinia sappan L) as Producer of Antioxidant \\ Compounds
}

\author{
Amirullah, Sartini, Firzan Nainu \\ Fakultas Farmasi, Universitas Hasanuddin, Makassar, Indonesia, 90245
}

\author{
Article Info: \\ Received: 01 March 2019 \\ in revised form: 05 March 2019 \\ Accepted: 20 March 2019 \\ Available Online: 20 March 2019 \\ Keywords: \\ Endosymbionts \\ Caesalpinia sappan \\ DPPH \\ Antioxidant \\ Corresponding Author: \\ Firzan Nainu \\ Fakultas Farmasi, Universitas \\ Hasanuddin \\ Makassar, 90245, \\ Indonesia \\ Phone: +62 411588556 \\ Email: firzannainu@unhas.ac.id
}

\begin{abstract}
Endophytic fungi are microbes that reside symbiotically in the plant tissues with undetected negative impacts to their host plants. These fungi are able to produce elements similar to those produced by their host plants. Secang (Caesalpinia sappan L.) has been known as one of the medicinal plants that contains compounds with antioxidant activity thus promote a hypothesis that its endophytic fungi may yield a similar antioxidant effect. In this study, the isolation of endophytic fungi from Secang as the producer of antioxidant compounds was carried out. At the initial stage, endophytic fungi were isolated from the leaves, the twigs, the stems, and the roots of Secang using the agar plate method. Pure fungi isolates were then subjected to fermentation process using the PDB growth medium supplemented with yeast extract and were constantly shaken for 12 days at a speed of $200 \mathrm{rpm}$ to produce secondary metabolites. Fermentates obtained from all fungi isolates were then extracted using ethyl acetate and further tested for their antioxidant activities. In this study, of 19 isolates that were obtained from four parts of the Secang, five fungi isolates, coded as IFD1, IFD4, IFR5, IFA1, and IFA2 were found to yield antioxidant activities demonstrated by the presence of yellow spots on the chromatogram.
\end{abstract}

How to cite (APA 6th Style):

Amirullah., Sartini., Nainu, F. (2019). Isolasi Fungi Endofit dari Tanaman Secang (Caesalpinia sappan L), Sebagai Penghasil Senyawa Antioksidan. Jurnal Farmasi Galenika : Galenika Journal of Pharmacy, 5(1), 26-32. doi:10.22487/j24428744.2019.v5.i1.12013 


\begin{abstract}
ABSTRAK
Fungi endofit hidup bersimbiosis di dalam jaringan tanaman tanpa memberikan efek berbahaya bagi inangnya. Fungi endofit tersebut mampu menghasilkan senyawa yang mirip dengan yang dihasilkan oleh tanaman inangnya. Secang (Caesalpinia sappan L.) merupakan salah satu tanaman obat yang telah diketahui memiliki kandungan senyawa dengan aktivitas antioksidan sehingga mendorong hipotesis bahwa fungi endofit yang ada di dalamnya dapat menghasilkan efek antioksidan yang serupa. Pada penelitian ini, isolasi fungi endofit dari Secang sebagai penghasil senyawa antioksidan telah dilakukan. Pada tahap awal, isolasi fungi endofit dari daun, ranting, batang, dan akar Secang dilakukan dengan metode agar cawan. Isolat murni selanjutnya diproses melalui fermentasi menggunakan media PDB yang ditambahkan dengan ekstrak yeast dan dikocok selama 12 hari pada kecepatan $200 \mathrm{rpm}$ untuk memproduksi senyawa metabolit sekunder. Fermentat yang diperoleh kemudian diekstraksi dengan etil asetat untuk memperoleh ekstrak yang akan digunakan dalam pengujian aktivitas antioksidan. Dalam penelitian ini diperoleh 19 isolat dari empat bagian tanaman dimana lima isolat fungi, dengan kode IFD1, IFD4, IFR5, IFA1, dan IFA2 diketahui memiliki aktivitas antioksidan yang terlihat dengan adanya spot kuning pada kromatogram.
\end{abstract}

Kata Kunci : Endosimbion, Caesalpinia sappan, DPPH, Antioksidan

\section{PENDAHULUAN}

Produk alami yang ditemukan dari berbagai sumber alam umumnya berupa metabolit sekunder yang diproduksi oleh organisme sebagai respons terhadap rangsangan eksternal misalnya perubahan nutrisi atau infeksi akibat serangan pathogen (Strohl, 2001; Tan et al. 2001). Melalui serangkaian penelitian, telah diketahui bahwa tanaman maupun mikroba dapat menghasilkan metabolit sekunder dengan berbagai aktivitas biologik yang ternyata berkhasiat untuk mengobati berbagai penyakit (Radji, 2005; Strobel and Daisy, 2003).

Salah satu mikroba yang saat ini memperoleh perhatian cukup besar dalam dunia farmasi dan kedokteran adalah fungi endofit, Fungi ini merupakan organisme multiseluler yang menetap didalam jaringan tanaman tanpa memberikan efek berbahaya bagi tanaman tersebut. Selain itu, fungi endofit dapat menghasilkan senyawa metabolit yang memiliki aktivitas serupa dengan yang dihasilkan oleh tanaman inangnya (Radji, 2005).

Dewasa ini, beberapa penyakit/gangguan termasuk penuaan dini dan kanker telah diketahui timbul akibat meningkatnya serangan radikal bebas (Ames and Shigenaga, 1992). Radikal bebas merupakan istilah ilmiah untuk atom-atom atau molekul-molekul yang memiliki elektron tanpa pasangan. Atom maupun molekul tersebut cenderung kurang stabil dan akan berupaya untuk mencari elektron yang lain untuk saling berpasangan (Clarkson and Thompson, 2000). Radikal bebas dapat masuk ke dalam tubuh dan menyerang sel-sel yang sehat sehingga menyebabkan sel-sel tersebut kehilangan fungsi dan strukturnya dan pada akhirnya berpotensi menyebabkan terjadinya kanker (Liochev, 2013). Untuk mengatasi radikal bebas, tubuh telah dilengkapi dengan sistem antioksidan endogen termasuk di antaranya melalui bantuan enzim superoxide dismutase (SOD), enzim catalase, dan beberapa enzim lainnya yang diproduksi sebagai respon terhadap peningkatan radikal bebas (Daniel et al. 2010). Akan tetapi, dalam kasus peningkatan radikal bebas yang terlalu berlebihan, penggunaan senyawa antioksidan eksogen sangat diperlukan oleh tubuh agar mencegah terjadinya stres oksidatif yang berkepanjangan.

Salah satu tanaman yang memiliki potensi sebagai penghasil senyawa antioksidan eksogen adalah Secang (Caesalpinia sappan L.) (Lim et al. 1996; Utari, 2017). Menurut Utari (2017), ekstrak kayu Secang memiliki aktivitas antioksidan berdasarkan analisis menggunakan metode DPPH (2,2-difenil-1-pikrilhidrazil) dimana ekstrak Secang memiliki nilai $\mathrm{IC}_{50}$ sekitar $15,69 \mathrm{ppm}$ sehingga dikategorikan sebagai ekstrak dengan aktivitas antioksidan yang sangat kuat. Hingga saat ini, beberapa senyawa yang dihasilkan oleh fungi endofit 
termasuk di antaranya pestacin dan isopestacin yang dihasilkan oleh endofit $P$. microspora, telah dilaporkan memiliki aktivitas sebagai senyawa antioksidan. Senyawa-senyawa tersebut diduga berhasiat sebagai antioksidan karena struktur molekulnya mirip dengan flavonoid (Strobel, 2002).

Berangkat dari konsep bahwa tanaman secang memiliki kandungan senyawa antioksidan yang sangat poten dan fungi endofit memiliki kemampuan untuk menghasilkan senyawa serupa tanaman inangnya, kami memiliki hipotesis bahwa fungi endofit tanaman Secang dapat digunakan sebagai sumber alternatif untuk menghasilkan senyawa antioksidan poten tersebut. Hipotesis tersebut kemudian kami buktikan melalui serangkaian eksperimen yang dilakukan dalam penelitian ini.

\section{METODE PENELITIAN}

\section{Alat dan bahan}

Alat-alat yang digunakan dalam penelitian ini meliputi Laminar air flow (LAF), lemari pendingin, lampu UV $254 \mathrm{~nm}$ dan $366 \mathrm{~nm}$, Inkubator (Memmert), Autoklaf (Hirayama HVA-85), oven (Memmert) shaker, cawan petri (Normax), timbangan analitik (Henher Scale), gelas Erlenmeyer (Pyrex), gelas kimia 250 dan $500 \mathrm{ml}$ (Pyrex), pipa kapiler, dan vial. Adapun bahan-bahan yang digunakan dalam penelitian ini adalah aquadest, etil asetat, etanol 70\%, media Potato dextrosa agar (PDA, Merck ${ }^{\circledR}$ ), potato dextrosa broth (PDB, Merck ${ }^{\circledR}$ ), metanol $\left(\right.$ Merck $\left.^{\circledR}\right)$, etil asetat $\left(\right.$ Merck $\left.^{\circledR}\right)$, klorofom, kloramfenikol, DPPH (1,1-difenil-2-pikrilhidrazil), ekstrak yeast, Natrium hipoklorit ( $\mathrm{NaClO}) 5,25 \%$, Lactophenol blue, dan lempeng KLT GF254.

\section{Prosedur Penelitian}

\section{Isolasi fungi endofit dari tanaman Secang}

Sampel yang diperoleh dari tanaman Secang, berupa daun, ranting, batang, dan akar terlebih dahulu dibersihkan dan dicuci dengan air mengalir selama 5 menit.Selanjutnya direndam menggunakan etanol $70 \%$ selama 5 menit. Sampel kemudian dibilas menggunakan aquadest steril. Masing-masing bagian tanaman dipotong-potong kurang lebih $1 \times 2 \mathrm{~cm}$ dan dilanjutkan dengan sterilisasi permukaan, berturutturut menggunakan larutan etanol $70 \%$ selama 3-5 menit dan $\mathrm{NaClO} \mathrm{5,25 \%} \mathrm{selama} \mathrm{3-5} \mathrm{menit} \mathrm{untuk}$ bagian akar dan kulit batang dan 1-3 menit untuk bagian daun dan ranting. Potongan tanaman kemudian dikeringkan di atas kertas saring steril, kemudian dibelah menjadi dua bagian yang sama. Potongan sampel selanjutnya ditempelkan secara aseptik pada permukaan media PDA steril yang mengandung antibiotik kloramfenikol $0.05 \%$ lalu diinkubasi pada suhu kamar selama 5 sampai 14 hari. Bentuk dan warna koloni isolat fungi yang diperoleh kemudian diamati dan selanjutnya masing-masing isolat dengan bentuk dan warna koloni yang berbeda dipindahkan ke dalam media PDA berulang kali sampai diperoleh kultur murni. Setiap koloni yang murni dipindahkan ke media PDA miring untuk disimpan sebagai kultur persediaan (stock culture) dan kultur kerja (working culture) (Sartini et al. 2011).

\section{Produksi metabolit sekunder}

Pembuatan kultur starter dibuat dengan cara mensuspensikan koloni yang tumbuh pada media agar miring dengan menggunakan aquadest steril kemudian dituang ke dalam erlemeyer yang berisi medium PDB yang telah ditambahkan ekstrak yeast (PDY). Selanjutnya, campuran diinkubasi pada suhu $25{ }^{\circ} \mathrm{C}$ selama 3 - 5 hari. Sebanyak $50 \mathrm{ml}$ kultur starter dimasukkan ke dalam $200 \mathrm{ml}$ medium PDY kemudian dishaker selama 12 hari pada suhu $25^{\circ} \mathrm{C}$ (Sartini et al. 2011).

\section{Identifikasi fungi endofit secara makroskopik.}

Identifikasi makroskopik dilakukan untuk mengetahui bentuk morfologi dari isolat yang diperoleh dari proses isolasi. Identifikasi ini dilakukan melalui pengamatan langsung warna permukaan koloni dan bentuk koloni (Summerbell, 1996).

\section{Ekstraksi hasil fermentasi}

Hasil fermentasi yang diperoleh dari proses fermentasi tiap isolat fungi endofit kemudian diekstraksi sebanyak dua kali dengan menggunakan pelarut etil asetat $(1: 1 \mathrm{v} / \mathrm{v})$ dalam corong pisah selama 20 menit. Selanjutnya ekstrak yang diperoleh diuapkan lalu disimpan pada desikator untuk digunakan pada uji selanjutnya (Peterson et al.2005).

\section{Uji aktivitas antioksidan secara kromatografi}

Pengujian aktivitas antioksidan dilakukan secara kualitatif menggunakan metode kromatografi lapis tipis (KLT) dimana ekstrak fermentat ditotolkan pada lempeng KLT GF254 dan dielusi menggunakan fase gerak klorofom:metanol dengan perbandingan 8:1. Selanjutnya hasil kromatogram kemudian disemprot dengan larutan DPPH. Hasil positif 
diindikasikan oleh terbentuknya spot warna kuning dengan latar ungu pada lempeng KLT yang menunjukkan kandungan senyawa dengan aktivitas antioksidan (Demirezer et al. 2001).

\section{HASIL DAN PEMBAHASAN}

Eksperimen untuk mengisolasi fungi endofit tanaman Secang (C. sappan L.) memberikan hasil berupa 19 isolat fungi endofit yang memiliki karakteristik warna dan bentuk yang berbeda (Gambar 1 dan Tabel 1). Dari Gambar 1 dan Tabel 1 terlihat bahwa 19 isolat fungi endofit berhasil diisolasi dari empat bagian tanaman Secang $(C$. sappan L.) yang digunakan dalam penelitian ini. Lima isolat (kode IFD1-IFD5) diperoleh dari bagian daun, delapan isolat (kode IFR1-IFR8) diperoleh dari bagian ranting, tiga isolat (kode IFB1-IFB3) diperoleh dari bagian batang, dan tiga isolat (kode IFA1-IFA3) diperoleh dari bagian akar, dimana isolat-isolat fungi yang diperoleh memiliki karakteristik morfologi yang berbeda meliputi warna, dan bentuk koloni. Seluruh isolat yang diperoleh kemudian diproses ke dalam uji skrining aktivitas metabolit sekunder terhadap beberapa bakteri uji (data tidak ditampilkan). Dari pengujian skrining antibakteri diperoleh lima isolat fungi endofit yang memiliki potensi antibakteri. Selanjutnya, kelima isolat fungi endofit tersebut diproses ke dalam pengujian aktivitas antioksidan menggunakan DPPH untuk melihat potensi aktivitas antioksidannya. Pada penelitian kali ini, tidak semua isolat fungi endofit yang diperoleh dilanjutkan ke pengujian aktivitas antioksidan.

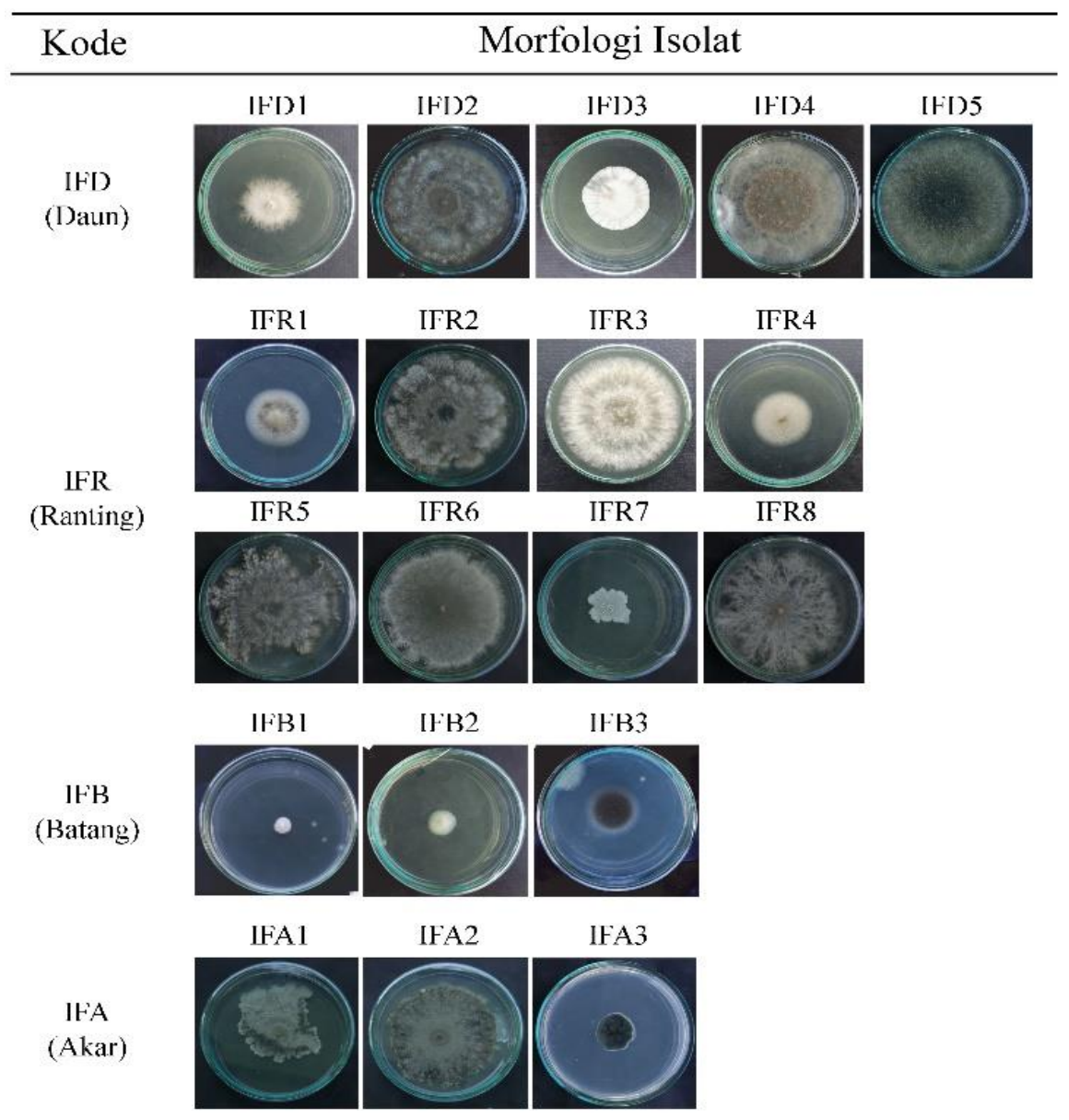

Gambar 1. Karakteristik morfologifungi endofit tanaman Secang (C. sappan L.).

Ket: IFD Isolat Fungi Daun, IFR Isolat Fungi Ranting, IFB Isolat Fungi Batang, IFA Isolat Fungi Akar. 
Tabel 1. Karakteristik hasil isolasi fungi endofit tanaman Secang (C. sappan L.)

\begin{tabular}{|c|c|}
\hline $\begin{array}{l}\text { Kode } \\
\text { Isolat }\end{array}$ & $\begin{array}{l}\text { Ciri Makroskopik Fungi Endofit Hasil Isolasi } \\
\text { dari Secang (C. sappan L.) }\end{array}$ \\
\hline IFR1 & $\begin{array}{l}\text { Warna koloni coklat kehitaman, warna } \\
\text { miselia putih keabu-abuan, bentuk koloni } \\
\text { circular }\end{array}$ \\
\hline IFR2 & $\begin{array}{l}\text { Warna koloni putih dengan bentuk circular, } \\
\text { pertumbuhan miselia halus }\end{array}$ \\
\hline IFR3 & $\begin{array}{l}\text { Warna koloni putih dengan bentuk circular, } \\
\text { pertumbuhan miselia halus dan melebar. }\end{array}$ \\
\hline IFR4 & $\begin{array}{l}\text { Warna koloni putih cream, berbentuk circular } \\
\text { pertumbuhan miselia padat dan agak rapat }\end{array}$ \\
\hline IFR5 & $\begin{array}{l}\text { Warna koloni coklat kehitaman, bentuk } \\
\text { koloni irregular, pertumbuhan miselia halus } \\
\text { agak berwarna putih }\end{array}$ \\
\hline IFR6 & $\begin{array}{l}\text { Warna koloni abu-abu, berbentuk circular, } \\
\text { pertumbuhan miselia halus dan rapat }\end{array}$ \\
\hline IFR7 & $\begin{array}{l}\text { Warna koloni putih gading, berbentuk } \\
\text { circular, berlendir dan tidak memiliki miselia }\end{array}$ \\
\hline IFR8 & $\begin{array}{l}\text { Warna koloni putih, berbentuk irregular } \\
\text { dengan pertumbuhan miselia menyebar dan } \\
\text { halus. }\end{array}$ \\
\hline IFB 1 & $\begin{array}{l}\text { Warna koloni putih berbentuk circular } \\
\text { dengan pertumbuhan miselia menyebar dan } \\
\text { halus }\end{array}$ \\
\hline IFB2 & $\begin{array}{l}\text { Warna koloni putih agak kekuningan } \\
\text { berbentuk circular, miselium menyebar dan } \\
\text { halus }\end{array}$ \\
\hline IFB3 & $\begin{array}{l}\text { Warna koloni coklat dengan warna miselia } \\
\text { putih keabu-abuan, pertumbuhan miselia } \\
\text { menyebar dan halus }\end{array}$ \\
\hline IFA1 & $\begin{array}{l}\text { Warna koloni berwarna abu-abu kehitaman, } \\
\text { dengan bentuk koloni irregular, pertumbuhan } \\
\text { isolat terlihat kaku dan mengeras }\end{array}$ \\
\hline IFA2 & $\begin{array}{l}\text { Warna koloni hitam dengan warna miselia } \\
\text { abu-abu tua, koloni berbentuk circular, } \\
\text { pertumbuhan isolat terlihat kaku dan keras }\end{array}$ \\
\hline IFA3 & $\begin{array}{l}\text { Warna koloni hitam, berbentuk circular } \\
\text { dengan pertumbuhan koloni yang kasar. }\end{array}$ \\
\hline IFD1 & $\begin{array}{l}\text { Warna koloni putih dengan bentuk koloni } \\
\text { circular, pertumbuhan miselia menyebar dan } \\
\text { halus }\end{array}$ \\
\hline IFD2 & $\begin{array}{l}\text { Warna koloni coklat dengan miselia berwarna } \\
\text { abu, bentuk koloni circular, pertumbuhan } \\
\text { miselia menyebar dan halus }\end{array}$ \\
\hline IFD3 & $\begin{array}{l}\text { Warna koloni putih berbentuk circular } \\
\text { dengan pertumbuhan miselia menyebar dan } \\
\text { halus }\end{array}$ \\
\hline IFD4 & $\begin{array}{l}\text { Warna koloni putih agak kekuningan } \\
\text { berbentuk circular, miselium menyebar dan } \\
\text { halus }\end{array}$ \\
\hline IFD5 & $\begin{array}{l}\text { Warna koloni coklat dengan warna miselia } \\
\text { putih keabu-abuan, pertumbuhan miselia } \\
\text { menyebar dan halus }\end{array}$ \\
\hline
\end{tabular}

Fermentasi metabolit sekunder fungi endofit dilakukan dengan metode fermentasi cair menggunakan medium PDY (medium PDB yang telah ditambahkan ekstrak yeast) kemudian dikocok selama 12 hari pada suhu ruangan. Setelah proses fermentasi dilakukan, fermentat kemudian disaring untuk memisahkan biomassa dan cairan fermentat. Cairan fermentasi diekstraksi dalam corong pisah menggunakan pelarut etil asetat $(1: 1 \mathrm{v} / \mathrm{v})$ dalam corong pisah kemudian diuapkan. Penggunaan pelarut etil asetat dikarenakan oleh sifat senyawa etil asetat yang mampu menarik senyawa polar dan non polar yang ada dalam cairan fermentat, sesuai konsep like dissolve like (Ansel, 1989) dimana senyawa yang bersifat polar akan larut ke dalam bagian polar dari pelarut dan senyawa bersifat nonpolar akan larut ke dalam bagian nonpolar. Selanjutnya ekstrak yang diperoleh kemudian digunakan dalam pengujian aktivitas antioksidan.

Pada pengujian aktivitas antioksidan secara kualitatif digunakan metode kromatografi lapis tipis kontak. Pada proses elusi menggunakan fase diam silika gel GF254 dan fase gerak eluen campuran klorofom:metanol dengan perbandingan 8:1. Lempeng kromatogram yang telah dielusi kemudian disemprot dengan larutan DPPH. Pada lempeng tersebut terlihat bercak berwarna kuning dengan latar ungu sesaat setelah penyemprotan DPPH dilakukan, mengindikasikan bahwa ekstrak tersebut memiliki kandungan senyawa dengan potensi antioksidan. Uji antioksidan DPPH didasarkan pada kemampuan senyawa aktif antioksidan untuk meredam aktifitas radikal bebas DPPH yang berwarna ungu membentuk senyawa stabil non-radikal yang bewarna kuning. Aktivitas penambahan senyawa DPPH menunjukkan adanya kemampuan senyawa antioksidan untuk mendonorkan elektron atau hidrogen sehingga merubah radikal menjadi nonradikal yang lebih stabil (Bougatef et al. 2009).

Menurut Sutomo et al. (2013), bercak noda pada lempeng kromatogram (yang terindikasi memiliki aktivitas antioksidan) dapat menangkap radikal bebas dan menghasilkan warna kuning dengan warna latar ungu dalam waktu tidak lebih dari 30 menit. Hasil pengujian kami menunjukkan bahwa spot kuning terbentuk pada lempeng kromatogram hasil fermentasi lima isolat, yaitu isolat dengan kode IFD1, IFD4, IFR5, IFA1, dan IFA2 dalam waktu kurang dari 30 menit, mengindikasikan bahwa kelima sampel tersebut memiliki aktivitas antioksidan (Gambar 2). Dari hasil ini terlihat bahwa fungi endofit yang berhasil diisolasi dari bagian daun, 
ranting, dan akar Secang mampu menghasilkan metabolit sekunder yang terindikasi memiliki aktivitas antioksidan. Hal ini sesuai dengan hasil penelitian sebelumnya yang melaporkan bahwa ekstrak daun dan ekstrak batang Secang (C. sappan L.) mengandung senyawa yang memiliki aktivitas antioksidan (Harjit et al. 2016; Utari, 2017). Namun sayangnya, dalam penelitian ini kami tidak melakukan pengujian terhadap fungi endofit yang berhasil diisolasi dari bagian batang. Walaupun demikian, berdasarkan pengujian aktivitas antioksidan terlihat bahwa ekstrak daun maupun ekstrak metabolit sekunder fungi endofit yang berhasil diisolasi dari daun Secang (C. sappan L.) dapat menghasilkan senyawa dengan aktivitas antioksidan serupa, mengindikasikan bahwa transfer genetik dapat terjadi antara fungi dengan tanaman inangnya untuk menghasilkan senyawa yang memiliki aktivitas antioksidan. Pada akhirnya, untuk membuktikan keberadaan proses transfer genetik antara Secang (C. sappan L.) dan fungi endofitnya (maupun sebaliknya), maka isolasi dan karakterisasi senyawa dengan aktivitas antioksidan yang berasal baik dari bagian tanaman maupun fungi endofit dari bagian tanaman tersebut perlu untuk dilakukan di kemudian hari.

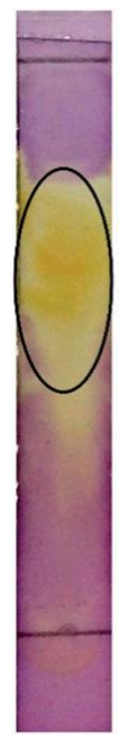

IFD1 IFD4

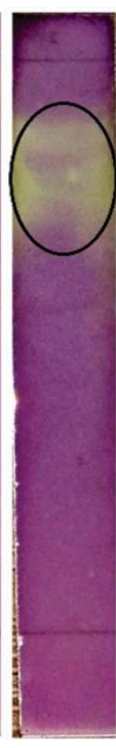

IFR5

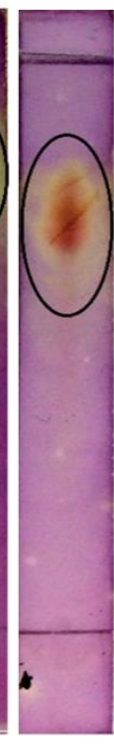

IFA1

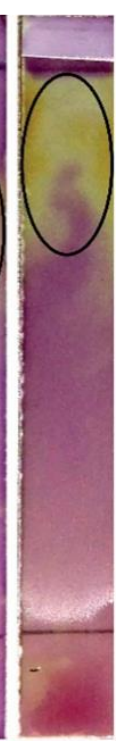

IFA2
Gambar 2. Hasil identifikasi secara kromatografi dan pengujian aktivitas antioksidan isolat fungi endofit dari Secang (C. sappan L.).

Ket: IFD Isolat Fungi Daun, IFR Isolat Fungi Ranting, IFA Isolat Fungi Akar.

\section{KESIMPULAN}

Dari tanaman Secang (C. sappan L.) diperoleh 19 isolat fungi endofit yang terdiri dari lima isolat dari bagian daun, delapan isolat dari bagian ranting, tiga isolat dari bagian batang, dan tiga isolat dari bagian akar. Dari jumlah isolat yang diperoleh terdapat lima isolat fungi endofit dengan kode IFD1, IFD4, IFR5, IFA1 dan IFA2 yang telah dibuktikan memiliki aktivitas antioksidan.

\section{UCAPAN TERIMAKASIH}

Penulis mengucapkan terima kasih kepada rekanrekan dalam tim penelitian di grup FN. Penelitian yang dilaksanakan oleh grup FN dibiayai oleh Universitas Hasanuddin menggunakan skema biaya Benua Maritim Indonesia Spesifik (BMIS) dan World Class University (WCU).

\section{DAFTAR PUSTAKA}

Ames, B.N., Shigenaga, M.K. (1992). DNA damage by endogenous oxidants and mitogenesis as causes of aging and cancer. In: Scandalios (ed.), Molecular Biology of Free Radical Scavenging Systems. Cold Spring Harbor Laboratory Press. pp.1-2.

Ansel, H.C. (1989). Pengantar bentuk sediaan farmasi. Edisi 4. UI Press. Jakarta. hal 96, 147.

Bougatef, A., Muhammed, H., Rafik, B., Imen, L., Yosra, T.E. and Moncef, N. (2009). Antioxidant and free radical-scavenging activities of smooth hound (Mustelus) muscle protein hydrolysates by gastrointestinal proteases. Food Chemical. 114:1198-12.

Clarkson, P.M and Thompson, H.S. (2000). Antioxidants: what role do they play in physical activity and health? Am. J. Clin. Nut. 72(2 Suppl):637S-46S.

Daniel, R.M., Stelian, S., and Dragomir, C. (2010). The effect of acute physical exercise on the antioxidant status of the skeletal and cardiac muscle in the Wistar rat. Romanian Biotechnological Letters. 15(3) suppl:5661. 
Demirezer, L.O., Kruuzum-Uz, A., Bergere, I., Schiewe, H.J., \& Zeeck, A. (2001). The Structures of antioxidant and cytotoxic agents from natural source: Antraquinones and tannin from roots of Rumex patientia, Phytochemistry. 58:1213-1217.

Harjit, K., Amini, M.H., and Suttee, A. (2016). Evaluation of antioxidant and anthelmintic properties of Caesalpinia sappan L. leaves. International Journal of Pharmacognosy and Phytochemical Research. 8(2): 362368.

Liochev, S.I. (2013). Reactive oxygen species and the free radical theory of aging, Free Radical Biology and Medicine. 60:1-4.

Lim, D.K., Choi, U., and Shin, D.H. (1996). Antioxidative activity of some solvent extract from Caesalpinia sappan L. Korean Journal of Food Science and Technology. 28(1):77-82.

Peterson, S.W., Vega, F.E., Posada, F., and Nagai, C. (2005). Penicillium coffeae, a new endophytic species isolated from a coffee plant and its phylogenetic relationship to $P$. fellutanum and $P$. brocae based on parsimony analysis of multilocus DNA sequences, Mycologia.

Radji, M. (2005). Peran bioteknologi dan mikroba endofit dalam pengembangan obat herbal, Pharmaceutical Sciences and Research. 2(3):113-126.

Strohl, W.A, Rouse, H., and Fisher B.D. (2001). Lippincott Illustrated Reviews: Microbiology. Lippincott Williams \& Wilkins. USA.

Strobel, G.A. (2002). Microbial gifts from rain forests. Can J Plant Pathol. 24:14-20.

Strobel, G.A., and Daisy, B. (2003). Bioprospecting for microbial endophytes and their natural products. Microbiol Mol Biol Rev. 67(4):491-502.
Sartini, S., Asri, R.M., dan Ismail, I. (2017). Pengaruh pra perlakuan sebelum pengeringan sinar matahari dari kulit buah kakao terhadap kadar komponen fenolik dalam ekstrak. Bioma: Jurnal Biologi Makassar. 2(1): 15-20.

Summerbell, R. (1996). Identifying filamentous fungi: A clinical laboratory. Ontario Ministry of Health. Pennsylvania State university. pp. 15-20.

Sutomo, Wahyuono, S., Rianto, S., and Setyowati, E.P. (2013). Isolation and identification of active compound of $n$-hexane fraction from kasturi (Mangifera casturi Kosterm.) against antioxidant and immunomodulatory activity, J. Biol. Sci. 13(7):596-604.

Tan, R.X. and Zou, W.X. (2001). Endophytes: a rich source of functional metabolites. Nat Prod Rep. 18(4):448-459.

Utari, F.D. (2017). Produksi antioksidan dari ekstrak kayu secang (Caesalpinia sappan L.) menggunakan pengering berkelembaban rendah, Jurnal Aplikasi Teknologi Pangan. 6(3):1-4. 